\title{
The Censor in the Late Republican Empire and His Meaning
}

\section{for Modern Democracy}

\author{
Nico P. Swartz \\ Faculty of Law \\ Dept. Roman Law, UFS, PO Box 339, Bloemfontein 9300 \\ E-mail: swartznp.rd@ufs.ac.za
}

\begin{abstract}
In the Late Republican time, the censor was involved in maintaining and enforcing moral conduct amongst the citizenry. It had to guard the morals of the populace. The question to be asked now concerns the implications, for humanity in a modern democracy, of censuring the censor. This study determines that the functions of the censor display similarities with that of the Public Protector in a modern democracy. However, the functions of the censor belonged to the Late Republican time. Only centuries later, a bureaucracy, the Public Protector, appeared with functions similar to those of the censor. However, because of the constitutional demands of a modern democracy, the Public Protector had to fulfil additional and wider-ranging functions. Despite these larger and wider-ranging functions, the influence of the censor is clearly to be seen in the functions of the Public Protector.
\end{abstract}

Keywords: Censor, Public Protector, Roman Empire, Late Republican period, Human rights.

\section{Introduction}

Governments are seen as the protectors of the interests of the citizens and of its own interests. A democracy can only survive if the citizens have the assurance that their safety and other rights vis-à-vis other people and the government will be protected and respected. This will best be done if maintaining morally good acts amongst the citizenry as well as the bureaucracy is enhanced.

The censors of the Roman Empire display similar functions as government officials (for instance, the Public Protector) in a modern democracy. For purposes of this article, a study concerning the term, jurisdiction, and powers of the censor in the Late Republican period is hugely important. The article further aims at making relevant the role of censor for the modern democracy (under the Public Protector). The influence of the censor in the Late Republican Empire is still relevant and serves as the ground for maintaining morally good acts. On this basis, the protection of human rights in a modern democracy has been made possible.

\section{The origin of the censor}

The census was introduced by Servius Tullius, the sixth king of Rome. After disposing of the kings and founding the Republic, the census was replaced by the consuls in $443 \mathrm{BC}$ "Idem hic annus [443 BC] censurae initium fuit, rei a parva origine orate, quae deinde tanto incremento aucta est ut morum disciplinaeque Romanae penes eam regimen [...]" (Note 1) Because the census was labour intensive and beneath the dignity of a consul, the need arose for an appropriate bureaucracy, i.e. the censor, to fulfil this task. "[Cui] scribarum ministerium custodiaeque tabularum cura, cui arbitrium formulae censcendi subiceretur." (Note 2) The first censors were Papirius and Sempronius. (Note 3)

Up until 442 BC, no more consuls were elected, but only military tribunes. Because the military tribunes could also be plebeians (ordinary workers class), the patricians (nobility) feared that the plebeians would in due course obtain control over the census. The patricians thus terminated the tribunes and entrusted the job of census to two officials, the censors. They had to be elected from the patricians.

The patricians dominated the office of censor until 351 BC, when Gaius Marcius Rutilus was appointed as the first plebeian censor. (Note 4) Approximately 12 years later, a Publilian law decreed that at least one of the censors had to be a plebeian. (Note 5) In $131 \mathrm{BC}$, both censors were plebeians for the first time.

There were usually two censors. Should one of them die during his term of office, the other one replaced him. This happened only once in 393 BC when the Gauls occupied Rome. However, the Romans viewed this as "an offense against religion". (Note 6) Since then, if one of the censors were to die, his colleague had to resign and two new censors were elected to replace them. (Note 7)

The censor was involved in the regulation of the moral acts and discipline of the Roman citizens. (Note 8) There had to be no motive for financial gain from the office. For instance, Cato travelled from on village to the other in the mornings 
to hear cases. He then returned to his farm and worked in the fields with his slaves. (Note 9) He received no financial gain for his services.

\subsection{The term of office of the censor}

The Romans believed that the biggest protection of the freedom of citizens lie in the fact that positions of power were not to be of a lengthy nature, but that a time limitation had to be placed on them. (Note 10) Owing to ancient legislation, the term of office of the censor was initially determined as five years. Ten years after setting up the office, the term of office was reduced to 18 months by the dictator, Mamercus Aemilius Mamercinus by means of a law, the Aemelian law. (Note 11) Mamercus wrote: "Ut re ipsa" inquit "sciatis, Quirites, quam mihi diuturna non placeant imperia, dictatura me abdico." (Note 12) As far as the tension between the ancient legislation and the Aemelian law is concerned, the latter won because it was ordained after the ancient precept and practice required that later legislation should replace earlier legislation. "[Et] ideo Aemiliae potius legi paruerunt quam illi antiquae qua primum censores create errant, quia hanc postremam iusserat populus, et quia, ubi duae contrariae leges sunt, simper antique obrogat nova." (Note 13) On the one hand, this gesture by Mamercus was received favourably by the Roman citizenry. On the other hand, prominent patricians criticised this limitation on the term of office of the censor. The Aemelian law was binding on the censor and it remained valid for approximately 100 years after its proclamation. For example, the censor Appius Claudius was threatened with imprisonment if he did not obey the Aemelian laws. (Note 14)

\section{The election of the censor}

Censors were elected in the Centuriate meeting, with a consul as chairperson. (Note 15) Both censors had to be elected on the same day. If the election was not completed on the same day, it was considered invalid and a new meeting had to be held. (Note 16) Once the censors were elected and the censorial powers were granted to them by the decree, Lex Centuriata, they were thus installed in their office. (Note 17)

Only someone who has been consul was fit for the office of censor. (Note 18) There were no laws prohibiting someone from standing for censor twice. However, only one person was elected to the office of censor twice, namely Gaius Marcius Rutilus in 265 BC. In the same year, the latter decreed a law that entailed that now one could be elected as censor twice. For this, he received the nickname Censorinus. (Note 19)

\section{Features of the office of censor}

The office of censor was regarded as the highest in dignity in the Roman Empire. It was regarded as "sanctus magistratus" (sacred magestry) worthy of the highest respect. (Note 20) Persons filling this office had to bestow it with power and dignity. (Note 21)

The dignity of the office of censor was entrusted to this office on account of their maintaining and enhancing morally good acts amongst the citizenry. Based on this, the censors had at their disposal the regimen morum (the general control over the moral behaviour of citizens of the state). On basis of dignified features entrusted to this office, the censors had to allow themselves to be led by their own views (ad arbitrium censoris) and were not required to be responsible towards any other office in the state. (Note 22) This - responsibility towards other offices - could leave a loophole for the abuse of power.

\section{Duties of the censor}

The duties of the censor can be divided into three classes. Firstly, they had to register the citizens and their property; secondly, they had to guard over the regimen morum (maintaining the moral conduct of the citizens); and lastly, they had to supervise the finances of the state. (Note 23)

For purposes of this article, only the second duty of the censor will be discussed.

After the censors were relieved from the duty of public administration because of a lack of funding (in the state coffers), they then focussed their attention on maintaining public morality (regimen morum). (Note 24) The latter (duty) will be regarded as one of the most important duties of the censor. This made the office of censor into one of the most remarkable and feared in the Roman state. As far as the latter is concerned, the censors were also known as castigators (chastisers). In terms of this description, they were viewed as the maintainers of the public mores and morality. (Note 25) They were not only to prevent or punish crime or immoral acts by way of censure, but they also had to maintain the traditional character, ethics, and habits (mos majorum) of the Roman population. (Note 26)

\section{Censure (punishment by the censor)}

Die punishment imposed by the censor (censure) was preceded by the nota (mark, letter) or notatio, or animadversio censoria (censorial reproach) or praefectura (command). The Roman population habitually associated the rebuke (nota) with punishment and it would later be known as the nota censoria. Because, as previously noted, the censor was not required to report to anybody, the suspicion existed that they could abuse their power by being prejudiced. That the censors allowed themselves to be led by their discretion strengthened this suspicion. It was thus decided that censors 
were to perform an oath stating that they would not be prejudiced. The practical implication of this oath caused the censors to be bound in every case (on their list) to be able to name (subcriptio censoria) the name of the guilty person(s) and the punishment about to be meted out to him. (Note 27) This was most probably done to curb the prejudice of censors and to prevent the abuse of power.

The nota was only ignominia and not infamia. (Note 28) This meant that the punishment were not eternal in nature but could be undone by following censors or by way of a lex. Ignominia was of a transitory nature and most probably did not remove someone (who were preparing for an office) of his office, or disqualified him. (Note 29) For instance, Mamercus Aemilius was raised to dictator by the censor despite an official transgression and the following reproach. (Note 30)

However, the nota was not valid unless both censors agreed on the punishment.

The nota censoria was used to punish the following transgressions: if, for instance, and individual lived in celibacy during a time which citizens were forced by the state to marry in order to live as citizens of the state, (Note 31) the breaking up of a marriage, or engagement in an untoward way or for insufficient reasons, (Note 32) inappropriate behaviour towards women and children as well as insubordination of children towards parents, (Note 33) a luxury lifestyle or exorbitant waste of public funds, (Note 34) neglect or failure by and individual to cultivate his fields, (Note 35) cruelty towards slaves or clients and the perpetuation of scandalous trade or career, such as playing in theatres. (Note 36)

\subsection{Effect of the punishment (censure) of the censor}

By way of the nota censoria, a perpetuator could be excluded from or released of the rank of senator (ejection e senatu) by means of motio (removal). (Note 37) The punishment could entail the mere exclusion from the list of senators or a perpetuator could be demoted to an agriculturalist. (Note 38) By means of an ademptio equi, the state-subsidised horse of a guilty person (equestrian) was taken back from him in public. (Note 39) The punishment could be combined with both of the abovementioned. (Note 40) The motio e tribu entailed that a perpetrator was ostracised from his family. (Note 41) Lastly, the referre in aerarios or facere aliquem aerarium was imposed on any person whom the censors though deserving of such a punishment. This punishment included all other forms of punishment: "for an equestrian could not be made an aerarius unless he was previously deprived of a horse, nor could a member of a rustic tribe be made an aerarius unless he was previously excluded from it." (Note 42)

The Latin phrases iudicium censorium, gravitas censorial, and auctoritas conseria are indicative of the fact that the censors were persons endowed with power and thus able to make judgements and ascribe punishments. The censors usually put a mark (the nota censoria) behind the name of a (public official) senator who was found guilty of misconduct. Thomas wrote: "By affixing their mark of disapproval [nota censoria] to the name of an enrolled person, they could degrade him in rank and remove him from his tribe [...]" (Note 43) Wolf wrote about the nota censoria: "[It] [...] became [the censors] dreaded weapon." (Note 44) Because of the impact of the nota censoria, the censor was also vested with the competence to end the career of a senatorial official. (Note 45) They also maintained the right not to reappoint former members of the senate who, in their eyes, were unworthy. "[The] censors [...] deleting the names of those who had $[\ldots]$ in their opinion [...] by reason of misconduct, [be] unworthy to hold the senatorial dignity." (Note 46) The nota censoria also adversely affected the credit standing of a convicted senator. However, this did not hold for women because they were not tax payers, soldiers, or enfranchised citizens. (Note 47)

\section{The end of the censor}

The censor existed for 421 years, i.e. from 443 BC to 22 BC. This office was terminated by Lucius Cornelius Sulla. No census was performed between the time of Sulla's dictatorship and the first consulship (82-70 BC) of Gnaeus Pompeius Magnus (Pompey).

The strict maintenance of moral behaviour amongst citizens, which was supported by Sulla, was, however, disregarded by the aristocracy. This is proof of the fact that, during this period, the censor did not figure anymore. However, the censor revived again under the next consuls, i.e. Pompey and Marcus Licinius Crassus. Thus the power and influence of the censor could not be reinstated. (Note 48)

During the civil wars in Rome, no more censors were elected. After a long interlude, censors were once again appointed in 22 BC, when August caused Lucius Munatius Plancus and Aemilius Lepidus Paullus to fill this office. (Note 49) This was the last time that censors were appointed.

\section{Practical application: the duties of the censor vis-à-vis the Public Protector}

The powers of the censor resemble that of the Public Protector (Ombudsman in the previous dispensation, Ombudsman Act, Act 118 of 1979) in the current dispensation. The Public Prosecutor, however, has more powers than the censor had. In contrast to the censor, the Public Prosecutor can investigate "unfair, capricious, discourteous or other improper conduct or undue delay by a person performing a function connected with his or her employment by an institution or 
entity contemplated in paragraph (a)" (Note 50) According to this, it is clear that the Public Protector covers a much wider field than mere complaints concerning prejudice consequent upon the unlawful or improper conduct by the state or an official of the state in public capacity. The South African Legal Commission subsequently recommended that the Public Protector should also have the powers to investigate complaints that deal with the violation of environmental rights, fundamental rights and freedoms, complaints pertaining to corruption, bribery and the theft of state money. These recommendations of the Legal Commission are supported by sections 177(3) and (4) of the Constitution of South Africa, Act 108 of 1996. Apart from the Public Protector's duty to maintain moral acts, s/he also acts as the champion for the protection of basic human rights.

\section{Conclusion}

It is clear that the Public Protector performs similar functions to those of the censor. The duties of the censor were characteristic of the circumstances of the Late Republican period in the Roman Empire. The Public Protector's functions are requested by the demands of a modern democracy in order for the Protector to fulfil a wider-ranging function than that of the censor. Common to both offices is the fact that they are involved in maintaining morally good acts that serve as the basis for the protection of basic human rights. On this basis, the Public Protector can thus been regarded as the successor of the censor, despite the wider-ranging duties of the former. As said earlier, the larger duties of the Public Protector were necessitated by the need of a modern democratic dispensation. Apart from the wider-ranging duty, both offices have as common denominator the maintenance and enhancement of morally good acts amongst the citizenry. In this, the influence of the censors can be seen in the functions of the Public Protector when it concerns the maintenance of morally good acts amongst the citizenry amongst each other and vis-à-vis the public administration (state).

\section{References}

Cary, M \& Scullard, HHA. (1975). History of Rome down to the reign of Constantine (Butler \& Tanner Ltd.: Great Britain)

Cassius Dio, The Julio-Claudians: Selections from books 58-63 of the Roman history.

Cicero, De Legibus.

Cicero, De Re Publica.

Cicero, De Lege Agraria.

Cicero, Pro Cluentio Oratio.

Currie I and De Waal. (2005). The Bill of Rights Handbook 5th ed (Juta: Cape Town)

Nels W. Forde. (1975). Cato the Censor (Twayne Publishers: Boston)

Kunkel W. (1966). An Introduction to Roman Legal and Constitutional History (Clarendon Press: Oxford)

Livy vii. (1924). Foster, B.O. With an English translation. Books v, vi, vii. London: William Heinemann, G.P. Putnam's Sons: New York.

Livy v, vi, vii. (1926). A.R. Cluer, B.A. New Edition revised by P.E. Matheson. At the Clarendon Press: Oxford.

Livy iv. (1926). E. Capps, T.E. Page, W.H.D. Rouse (eds.). With an English translation by B.O. Foster, in thirteen volumes. Books viii-x. London: William Heinemann. G.P. Putnam's Sons: New York.

Livy xl-xlii. (1938). Even T. Sage and A.C. Schlesinger. With an English translation and text. Books xl-xlii. London: William Heinemann Ltd. Harvard University Press. Cambridge, Massachusetts.

Ombudsman Act, Act 118 of 1979.

Pliny, Natural History.

Plutarch. Makers of Rome: Nine lives by Plutarch (Penguin Books Ltd: Great Britain)

Plutarch, M. Cato I.4-5.

Public Protector Act, Act 23 of 1994.

Suetonius. (1982). Divus Augustus. (Bristol Classical Press: Great Britain)

Suolahti J. (1963). The Roman Censors (The Netherlands Co. Ltd.: Copenhagen)

Thomas J.A.C. (1976). Textbook of Roman Law (North-Holland Publishing Company: Amsterdam)

Valerius Maximus. (2000). With an English Translation and text by Bailey (William Heinemann Ltd.: London)

Wylie J.K. (1948). Roman Constitutional History (The African Bookman: Cape Town) 


\section{Notes}

Note 1. Livy iv: viii. "This same year saw the adoption of the censorship, an institution which originated in a small way but afterwards grew to such dimensions that it was invested with the regulation of the morals and discipline of the Romans."

Note 2. Livy iv: viii.

Note 3. Livy iv: viii.

Note 4. Livy vii xxii. "C. Marcius Rutulus, qui primus dictator de plebe fuerat [...]"

Note 5. Livy viii: xii. "Dictatura popularis et orationibus in patres criminosis fuit, et quod tres leges secundissimas plebei, adversas nobilitati tulit: unam, ut plebiscite omnes Quirites tenerent; alteram, ut legume, quae comitiis centur iatis ferrentur, ante initum suffragium patres auctores fierent; tertiam, ut alter utique ex plebe - cum eo ventum sit ut utrumque plebeium fieri liceret - censor crearetur."

Cf. Wylie 1948: 41.

Note 6. Livy v: xxxi. "C. Iulius censor decessit; in eius locum M. Cornelius suffectus, quae res postea religioni fuit quia eo lustro Roma est capta; nec deinde unquam in demortui locum censor sufficitur. Consulibusque morbo implicitis placuit per interregnum renovari auspicia. Itaque cum ex senatus consulto consules magistratu se abdicassent, interrex creatur M. Furius Camillus, qui P. Cornelium Scipionem, is deinde L. Valerium Potitum interregem prodidit. Ab eo create sex tribuni militum consulari potestate ut, etiam si cui eorum incommode valetudo fuisset, copia magistratuum rei publicae esset."

Note 7. Livy vi: xxvii; ix: xxxiv; xxiv: xliii; xxvii: vi. "Creati censores C. Sulpicius Camerinus Sp. Postumius Regillensis, coeptaque iam res morte Postumi, quia collegam suffice censori religio erat, interpellata est. Igitur cum Sulpicius abdicasset se magistratu censores alii vitio creati non gesserunt magistratum; tertios creari velut dis non accipientibus in eum annum censuram religiosum fuit."

Livy ix: xxxiv. "[Omnes] deinceps censores post mortem collegae se magistrate abdicarunt [...]"

Note 8. Livy iv: viii.

Note 9. Plutarch, M. Cato, I.4-5

Note 10. Livy ix: xxxiv.

Note 11. Livy iv: xxiv. "[Alios] magistratus annuos esse, quinquennalem censuram; grave esse iisdem per tot annos magna parte vitae obnoxios vivere; se legem laturum, ne plus quam annua ac semestris censura esset. Consensu ingenti populi legem postero die pertulit et 'Ut re ipsa' inquit 'sciatis, Quirites, quam mihi diuturna non placeant imperia, dictatura me abdico'. Deposito suo magistrate, imposito fine alteri, cum gratulatione ac favore ingenti populi domum est reductus. Censores aegre passi Mamercum quod magistratum populi Romani tribu moverunt octiplicatoque censu aerarium fecerunt."

Cf. Kunkel 1966: 18

Wylie 1948: 33.

Note 12. Livy iv: xxiv. "Mamercus explained, "That you may have positive proof, Quirites, how little I approve prolonged authority, I lay down my dictatorship."

Note 13. Livy ix: xxxiv. "[And] they obey the Aemilian law in preference to that ancient ordinance which governed the first elections of censors, precisely because it was the latest which the people had enacted, and because in a conflict of two laws the old is ever superseded by the new."

Note 14. Livy ix: xxxiv. "[Et] nisi Aemiliae legi parueris, in vincula duci iubebo [...]"

Note 15. Livy xl xlv. "Censorum inde comitia habita: create M. Aemilius Lepidus pontifex maximus et M. Fulvius Nobilior, qui ex Aetolis triumphaverat [...]. Comitiis confectis, ut traditum antiquitus est, censores in Campo ad aram Martis sellis curulibus consederunt; quo repente principes senatorum cum agmine venerunt civitatis, inter quos Q. Caecilius Metullus verba fecit."

Note 16. Livy ix: xxxiv.

Note 17. Livy xl: xlv; Cicero De Lege Agraria ii.11. "[Comitiis confectis, ut traditum antiquitus est, censores in Campo ad aram Martis sellis curulibus consederunt [...]"

Note 18. Wylie 1948: 31-2.

Note 19. Plutarch Life of Coriolanus 1.

Valerius Maximus iv: a.3 
Note 20. Plutarch Life of Cato the Elder 16.

Thomas 1976: 15.

Note 21.Livy iv: viii.

Vgl. Suolahti 1963: 14.

Thomas 1976: 15. "[Their] office became more august than even that of the consuls."

Note 22.Livy iv: xxiv. "[Mamercum] inquit 'Ut re ipsa, 'sciatus, Quirites, quam mihi diuturna non placeant imperia, dictatura me abdico [...] Censores aegre passi Mamercum quod magistratum populi Romani minuisset tribu moverunt octiplicatoque censu aerarium fecerunt [...] populi certe tanta indignatio coorta dicitur ut vis a censoribus nullius auctoritate praeterquam ipsius Mamerci deterreri quiverit."

Livy xxix: xxxvii. "[In] invidia censores cum essent, crescendo ex iis ratus esse occasionem Cn. Baebius tribunus plebis diem ad populum utrisque dixit. Ea res consensu partum discussa est, ne postea obnoxia populari aurae censura esset."

Note 23.Cicero De Legibus iii 3. "Censores, populi aevitates, soboles, famlias, pecuniasque censento: urbis templa, vias, aquas, aerarium, vectigalia tuento: populique partes in tribus distribuunto: exin pecunias, aevitates, ordinis patiunto: equitum, peditumque prolem describunto: caelibis esse prohibento: moris populi regunto: probrum in senatu ne relinquunto."

Note 24.Livy xxiv: xviii.

Note 25.Suolahti 1963: 39.

Note 26.Livy iv: viii. “[...] quae deinde tanto incremento aucta est ut morum disciplinaeque Romanae penes eam regimen, senatui equitumque centuriis decoris dedecorisque discrimen sub dicione eius magistratus, uis publicorum privatorumque locorum, vectigalia populi Romani sub nutu atque arbitrio eius essent."

Livy xxiv: xviii. “[...] ad mores hominum regendos animum adverterunt castigandaque vitia quae [...]”

Livy xl: xlvi. "Non obliti sumus, censores, vos Paulo ante ab universo populo Romano moribus nostris praepositos esse, et nos a vobis et admoneri et regi, non vos a nobis debere."

Livy xli: xxvii.

Livy xlii: iii.

Suetonius Life of Augustus 27. "[... sed reputans, et se privatum non sine periculo fore et illam plurium arbitrio temere committi, in retinenda perseveravit, dubium eventu meliore an voluntate. Quam voluntatem, cum prae se identidem ferret, quodam etiam edicto his verbis testatus est: 'ita mihi salvam ac sospitem rem publicam sistere in sua sede liceat, qtque eius rei fructum percipere, quem peto, ut optimi status auctor dicer, et moriens ut feram mecum spem, mansura in vestigio suo fundamenta rei publicae quae iecero. Fecitque ipse se compotem voti, nisus omni modo, ne quem novi status paeniteret. Urbem, neque pro maiestate imperii ornatam et inundationibus incendiisque obnoxiam, excoluit adeo, ut iure sit gloriatus marmoream se reliquere, quam latericiam accepisset."

Note 27. Livy xxxix: xlii. "Patrum memoria institutum fertur ut censores motis senatu adscriberent notas."

Cicero Pro Cluentio Oratio 42-8. "Video igitur, iudices, animadvertisse censores in iudices quosdam illius consilii Iuniani, cum istam ipsam causam subscriberent."

Note 28. Cicero De Re Publica iv: 6.

Note 29. Livy xxiv: xviii.

Note 30. Livy iv: xxxi. “A. Cornelius dictatorem Mam. Aemilium dixit et ipse ab eo magister equitum est dictus; adeo, simul fortuna civitatis virtute vera eguit, nihil censorial animadversio effecit quo minus regimen rerum ex notata indigne domo peteretur."

Cicero Pro Cluentio 42. "C. Getam, cum a L. Metello et Cn. Domitio censoribus ex senatu eiectus esset, censorum esse ipsum postea factum: et cuius mores errant a censoribus reprehensi, hunc postea et populi Romani et eorum, qui in ipsum animadverterant, moribus praefuisse."

Note 31.Valerius Maximus ii: 9. "Camillus et Postumius censores aera poenae nomine eos qui ad senectutem caelibes pervenerant in aerarium deferre iusserunt, iterum puniri dignos, si quidem de tam iusta constitutione queri sunt ausi, cum in hunc modum increparentur: 'Natura vobis quemadmodum nascendi ita gignendi legem scribit, parentesque vos alendo nepotum nutriendorum debito, si quis est pudor, alligaverunt. Accedit his quod etiam Fortuna longam praestandi huiusce muneris advocationem estis adsecuti, cum interim consumpti sunt anni vestri et mariti et patris nomine vacui. Ite igitur et nodosam exsolvite stipem, utilem posteritati numerosae."

Note 32.Valerius Maximus ii: 9. "L. enim Antonium senatu moverunt, quod quam virginem in matrimonium duxerat, 
repudiasset nullo amicorum consilio adhibito. At hoc crimen nescio an superiore maius: nam illo coniugalia sacra spreta tantum, hoc etiam iniuriose tractata sunt. Optimo ergo iudicio censores indignum eum aditu curiae existimaverunt."

Valerius Maximus ii: 9. "Repufium inter uxorem et virum a condita urbe usque ad vicesimum et quingentesimum annum nullum intercessit."

Note 33.Plutarch Life of Cato the Elder 17; Cicero De Re Publica iv 6.

Note 34.Plutarch Life of Cato the Elder 18.

Valerius Maximus ii: 9. "Narravit omnis aetas et deinceps narrabit ab eo Cornelium Rufinum duobus consulatibus et dictatura speciosissime functum, quod decem pondo vasa argentea comparasset, perind e ac malo exemplo luxuriosum in ordine senatorio retentum non esse."

Valerius Maximus ii: 9. "M. autem Antonius et L. Flaccus censores Duronium senatu moverunt, quod legem de coercendis conviviorum sumptibus latam tribunus plebi abrogaverat."

Cary and Scullard 1975: 82.

Forde 1975: 16. According to Forde, Cato had greatly respected Dentatus and imitated the latter's lifestyle: "[The] Samnite ambassadors found Dentatus cooking turnips for supper and attempted to bribe him. Dentatus threw the envoys out, saying that a man who could be satisfied with turnips fir supper had no need of gold; even if he did, it was more honourable to conquer those who had gold and gain it that way than merely possess gold - and conquer them he did. Meditating on the heroism of this man, Cato would return to his own hard work with renewed zeal."

Note 35.Valerius Maximus ii: 4. "Per quingentos autem et quinquaginta et octo annos senatus populo mixtus spectaculo ludorum interfuit. Sed hunc morem Atilius Serranus et L. Scribonius aediles ludos Matri deum facientes, posterioris Africani sententiam secuti [...]"

Valerius Maximus ii: 9. "Equestris quoque ordinis bona magnaque pars, quadrigenti iuvenes, censoriam notam patiente animo sustinuerunt, quos M. Valerius et P. Sempronius, quia in Sicilia ad munitionum opus explicandum ire iussi facere id neglexerant, equis publicis spoliatos in numerum aerariorum retulerunt."

Pliny Natural History xviii: 3.

Note 36.Livy vii: ii. "Et cum vis morbid nec humanis consiliis nec ope divina levaretur, victis superstitione animis ludi quoque scenici, nova res bellicose populo - nam circi modo spectaculum fuerat $[\ldots]$ "

Note 37.Livy xxxix: xlii. "Catonis et aliae quidem acerbate orationes exstant in eos quos aut senatorio loco movit [...]"

Note 38.Livy xxiv: xviii. The latter was rarely accepted.

Note 39.Livy xxxix: xlii. “[...] quibus equos ademit.”

Note 40. Livy xxxix: xlii; Livy xxiv: xviii, xliii.

Note 41.Livy xlv: xv. "Hoc cum ita servatum esset, negabat Claudius suffragii lationem iniussu populi censorem cuiquam homini, nedum ordini universo adimere posse. Neque enim, si tribu movere posit, quod sit nihil aliud quam mutare iubere tribum, ideo omnibus quinque et triginta tribubus emovere posse, id est civitatem libertatemque eripere, non, ubi censeatur, finire, sed censu excludere."

Vgl Cicero Pro Cluentio 43. "[...] in aerarios referre aut tribu movere iubeat [...]".

Note 42.Livy iv: xxiv; xx: xviii.

Note 43.Thomas 1976: 15.

Note 44.Wolff 1951: 35.

Note 45.Thomas 1976: 15.

Note 46.Wylie 1948: 38.

Note 47.Suolahti 1963: 49.

Note 48.Cassius Dio x1.57.

Note 49.Suetonius Life of Augustus 37.

Note 50.Section 6(4)(b) of the Public Protector Act, Act 23 of 1994. 